\title{
Gêneros midiáticos em foco: Analisando a organização textual- discursiva do programa televisivo Conexões Urbanas
}

Anna Christina Bentes (PQ), Ana Cecília A. Accetturi (IC).

\section{Resumo}

Nosso projeto tem por objetivo verificar o impacto de determinados recursos textuais-discursivos na configuração do programa Conexões Urbanas. Para isso, analisamos as mudanças temáticas que ocorreram no programa televisivo Conexões Urbanas ao longo dos sete anos de sua exibição. Para tanto, observamos os 111 episódios ques compõem as sete temporadas (2008-2015). Também fizemos um levantamento dos tipos de vozes e de edição que compõem os episódios do programa, observando uma amostra de 09 programas das três primeiras temporadas.

Palavras Chave: tema, programa televisivo, Conexões Urbanas.

\section{Introdução}

O programa Conexões Urbanas, que se propõe a ser e é visto como um tipo de "TV ação" ou ainda "TV mobilização" e que busca mostrar as "transformações sociais bem-sucedidas no Brasil e no mundo", apresentou 07 temáticas ao longo das temporadas e 02 tipos de vozes na composição dos textos do programa: especialistas (E) e não especialistas (N-E).

\section{Resultados e Discussão}

A análise feita dos 111 episódios do Conexões Urbana revela que ele apresenta sete diferentes temáticas:

Policiais, Outras Instituições, Indivíduos Questões sociais, Grupos sociais e Lugares de tensão social.

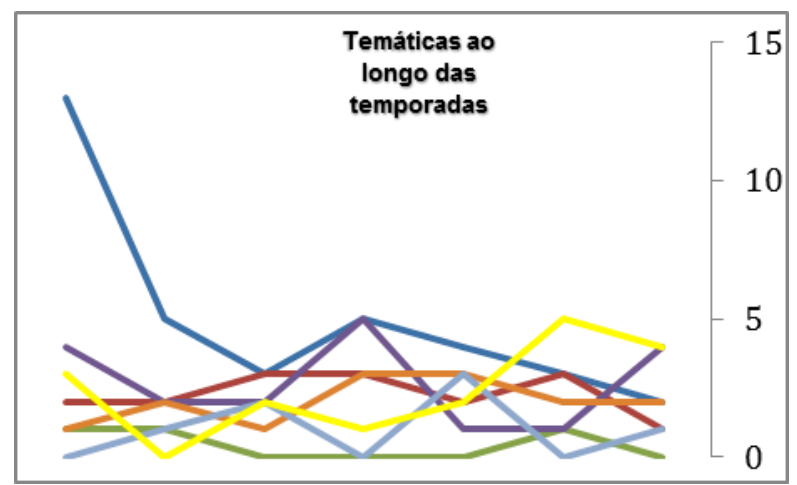

Gráfico 1: Trajetória das temáticas ao longo das sete temporadas do programa

A recorrência dessas temáticas permite vislumbrar como o programa foi mudando ao longo desses sete anos de exibição, priorizando, em sua última temporada (2014/2015), temáticas voltadas para questões sociais amplas e para trajetórias individuais. Vejamos agora os resultados do levantamento dos tipos de vozes que compõem os episódios do programa:

\begin{tabular}{|l|l|l|l|l|}
\hline \multirow{2}{*}{ Programas } & \multicolumn{4}{|c|}{ Tipos de vozes } \\
\cline { 2 - 5 } & Parte I & Parte II & Parte III & Final \\
\hline $\begin{array}{l}\text { Violência e } \\
\text { Prevenção } \\
(2008)\end{array}$ & E/N-E & N-E & N-E & N-E \\
\hline $\begin{array}{l}\text { Liberta Moda } \\
(2008)\end{array}$ & E & E & E & E \\
\hline $\begin{array}{l}\text { Empreendedor } \\
\text { ismo (2008) }\end{array}$ & N-E & N-E & N-E & E \\
\hline $\begin{array}{l}\text { Conflitos I } \\
\text { Polícia (2009) }\end{array}$ & E/ N-E & E & E & E/ N-E \\
\hline $\begin{array}{l}\text { Circo Social } \\
(2009)\end{array}$ & E & E & E & E \\
\hline $\begin{array}{l}\text { Pirataria } \\
(2009)\end{array}$ & E/ N-E & E & N-E & E/ N-E \\
\hline $\begin{array}{l}\text { Bangu } \\
(2010)\end{array}$ & N-E & E & E/ N-E & N-E \\
\hline $\begin{array}{l}\text { Saúde } \\
\text { Alegria (2010) }\end{array}$ & E & E & E & E \\
\hline $\begin{array}{l}\text { Complexo } \\
(2010)\end{array}$ & N-E & N-E & E & N-E \\
\hline
\end{tabular}

Tabela 1: Tipos das vozes no programa

Em relação aos tipos de vozes, percebemos que, nessa amostra, as dos especialistas podem ser equiparadas às dos não-especialistas.

\section{Conclusões}

A edição (modificações, cortes e inserções) do programa é responsável por mostrar mais de uma visão sobre uma mesma problemática, aumentando a legibilidade sobre o assunto em questão. Assim, a temática, a mobilização de diferentes vozes e a edição revelam que o programa Conexões Urbanas "faz diferença" na mídia televisiva, dado que apresenta temas não presentes na mídia tradicional, formatando-os a partir do centro de valor do grupo AfroReggae.

\section{Agradecimentos}

Instituição de fomento: CNPq.

\section{BIBLIOGRAFIA}

Bakhtin, M. M. Marxismo e filosofia da linguagem. 3a. ed. São Paulo: Hucitec, 1986. 196p. 